\title{
Accuracy in the Diagnosis of the Mental Nerve Loop. A Comparative Study Between Panoramic Radiography and Cone Beam Computed Tomography
}

\author{
Precisión en el Diagnóstico del Bucle del Nervio Mental. Estudio Comparativo \\ entre Radiografía Panorámica y Tomografía Computadorizada de Haz Cónico
}

\begin{abstract}
Carlos Eduardo Gomes do Couto-Filho*; Paulo Hemerson de Moraes*; Maria Beatriz Carrazzone Alonso**; Francisco Haiter-Neto"; Sergio Olate ${ }^{* * *, * * * * *}$ \& José Ricardo de Albergaria-Barbosa*
\end{abstract}

COUTO-FILHO, C. E. G.; DE MORAES, P. H.; ALONSO, M. B. C.; HAITER-NETO, F.; OLATE, S. \& ALBERGARIABARBOSA, J. R. Accuracy in the diagnosis of the position of the mental nerve loop. A comparative study between panoramic radiography and cone beam computed tomography. Int. J. Morphol., 33(1):327-332, 2015.

SUMMARY: Dental implant and chin osteotomy are executed on the mandible body and the mental nerve is an important anatomical limit. The aim of this research was to know the position of the mental nerve loop comparing result in panoramic radiography and cone beam computed tomography. We analyzed 94 hemimandibles and the patient sample comprised female and male subjects of ages ranging from 18 to 52 years (mean age, 35 years) selected randomly from the database of patients at the Division of Oral Radiology at Piracicaba Dental School State University of Campinas; the anterior loop (AL) of the mental nerve was evaluated regarding the presence or absence, which was classified as rectilinear or curvilinear and measurement of its length was obtained. The observations were made in the digital panoramic radiography (PR) and the cone beam computed tomography (CBCT) according to a routine technique. The frequencies of the AL identified through PR and CBCT were different: in PR the loop was identified in $42.6 \%$ of cases, and only $12.8 \%$ were bilateral. In contrast, the AL was detected in $29.8 \%$ of the samples using CBCT, with $6.4 \%$ being bilateral; Statistical comparison between PR and CBCT showed that the PR led to false-positive diagnosis of the AL in this sample. According to the results of this study, the frequency of AL is low. Thus, it can be assumed that it is not a common condition in this population.

KEY WORDS: Panoramic radiography; Cone-beam computed tomography; Mental nerve loop.

\section{INTRODUCTION}

The mental nerve $(\mathrm{MN})$ is a general somatic afferent nerve that provides sensation to the lip, chin, and gingival tissue. It is the terminal branch of the mandibular nerve, which is the third division of the trigeminal nerve. MN exits the mandible through the mental foramen, divides into 3 branches deep to the depressor angulioris muscle, and supplies the skin and mucous membrane of the lower lip, the skin of the chin, and the vestibular gingiva of the mandibular incisor (Jacobs et al., 2002). Anatomical literature has described the interforaminal region of the mandible as possessing a mental nerve with a path that creates an anterior loop (AL) before entering the mental foramina and another division in this point (anterior to the anterior loop of the mental nerve) as mandible incisive canal (Beltrán et al., 2011). The AL is described as an extension of the mental nerve that is anterior to the mental foramen (Benninger et al., 2011).
Treatment with dental implant and osteotomies are often complicated by the unknown extent of the anterior loop of the mental neurovascular bundle. Sensory disturbances of the mental nerve region may arise after endosseous implants are installed in the mandibular interforaminal. A relatively common problem is the use of an inappropriate attachment depth or path during the insertion of dental implant fixtures, which may damage the inferior alveolar nerve (IAN) and MN. The incidence of permanent sensory disturbance to the lower lip after dental implant insertion in the mental foramen area is reportedly $7 \%$ to $10 \%$ (Wismeijer et al., 1997; Mardinger et al., 2000). Complications such as loss of lip and chin sensation may result in lip biting, impaired speech, and diminished salivary retention, deficits that have a significant impact on a patient's activities of daily living (Mucci \& Dellon, 1997; Deeb et al., 2000).

* Division of Oral and Maxillofacial Surgery, Piracicaba Dental School, State University of Campinas, Piracicaba, Brazil.

** Department of Oral Diagnosis and Oral Radiology, Piracicaba Dental School, State University of Campinas, Piracicaba, Brazil.

*** CIMA Research Group, Division of Oral and Maxillofacial Surgery, Universidad de La Frontera, Temuco, Chile.

**** Center for Biomedical Research, Universidad Autónoma de Chile, Temuco, Chile. 
Preoperative radiographic examination is essential for selecting the sites for the installation of an optimum number of implants of optimal size. The potential location and angulations for each implant must be carefully determined and the operator must be familiar with the dimensions and shape of the jaws and the location of anatomical structures. Panoramic radiographs provide 2-dimensional information, while 3-dimensional determination requires tomography. Panoramic radiographs have severe limitations for the evaluation of anatomical structures and available bone for implants (Garay \& Olate, 2013; Garay et al., 2014). Preoperative tomography, is preferable, but is not always performed. Therefore, bone dimensions are usually assessed only by panoramic radiographic examinations.

Therefore, the aim of this research was to determine the correlation between the visual interpretation of the panoramic radiographs $(\mathrm{PR})$ and the cone beam computed tomography (CBCT) for the detection of the $\mathrm{AL}$ as well as the clinical relevance for planning the installation of dental implants.

\section{MATERIAL AND METHOD}

The patient sample comprised 47 female and male subjects of ages ranging from 18 to 52 years (mean age, 35 years). All of them were informed about the study and signed a document to participate in this research. The patient sample was selected randomly from the database of patients at the Division of Oral Radiology at Piracicaba Dental School State University of Campinas. The patients had to have undergone CBCT also had to undergone PR within the previous 6 months.

Digital panoramic radiographs were acquired in Orthopantomograph OP100 D, (Instrumentarium Corp., Imaging Division, Tuusula, Finland). The CBCT examinations were performed with an i-CAT CBCT unit (12bit Imaging Sciences International, Inc., Hatfield, PA, USA) using the exposure parameters recommended by the manufacturer: scan time, 40 seconds; $120 \mathrm{kVp}, 3-8 \mathrm{~mA}$; FOV, $13 \mathrm{~cm}$; voxel size $0.25 \mathrm{~mm}$. The resultant slice image

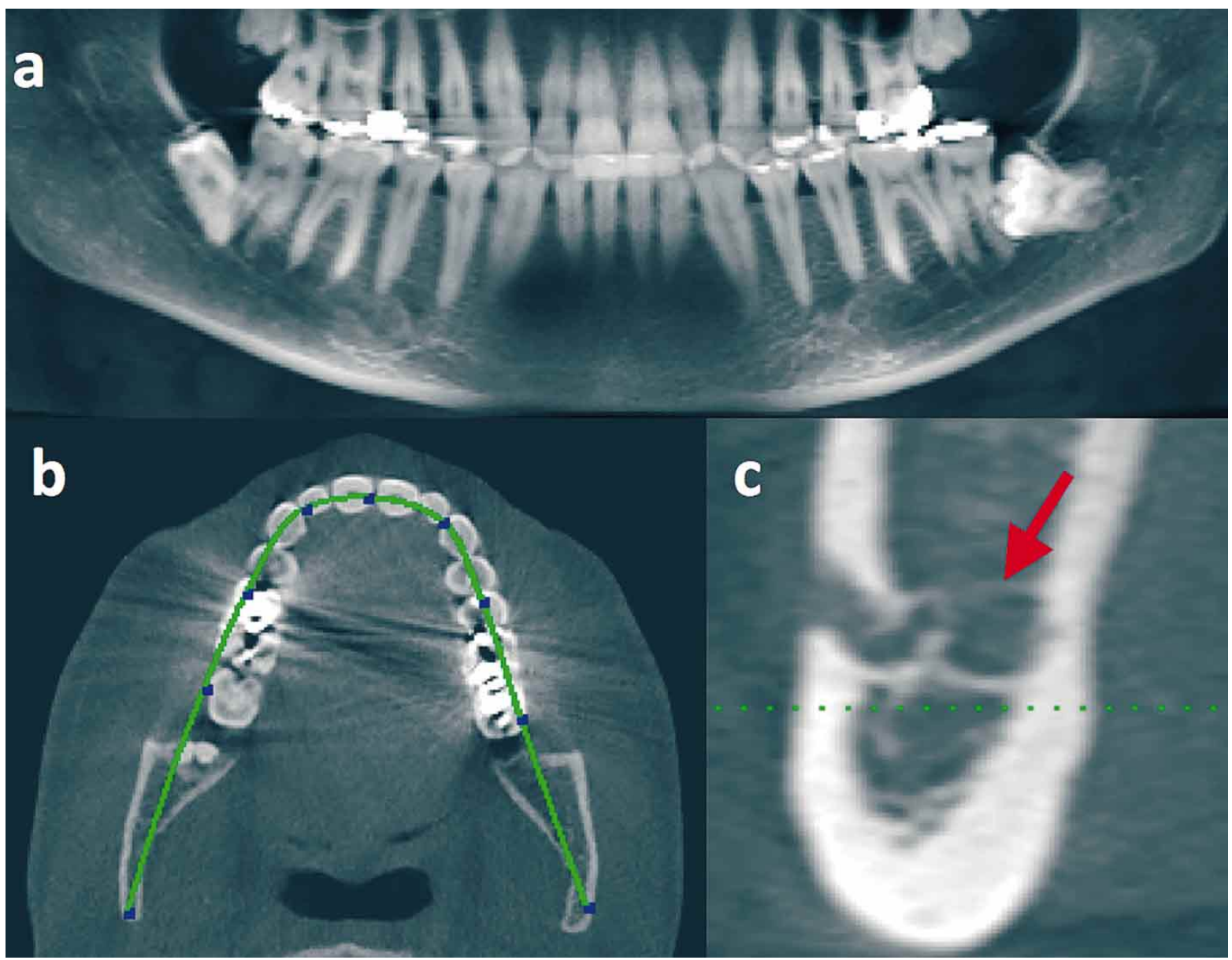

Fig. 1. A) Panoramic reconstruction from the CBTC, B) Axial view showing the final position of the inferior alveolar nerve, and C) cross-sectional image showing the anterior loop (AL) of the mental nerve (red arrow). 
COUTO-FILHO, C. E. G.; DE MORAES, P. H.; ALONSO, M. B. C.; HAITER-NETO, F.; OLATE, S. \& ALBERGARIA-BARBOSA, J. R. Accuracy in the diagnosis of the position of the mental nerve loop. A comparative study between panoramic radiography and cone beam computed tomography. Int. J. Morphol., 33(I):327-332, 2015.

data were converted to three-dimensional CT images in DICON format, reconstructed by XoranCat software (version 3.1.62). The reconstructed image was $2 \mathrm{~mm}$ (slice thickness), and cross-sectional CT images were obtained and evaluated in the same XoranCat software.

This study was divided into 2 steps: firstly panoramic radiography was performed for subjective evaluation of the trajectory of curvilinear AL, thus classified as present or absent (rectilinear) only on a total of 94 hemimandibles. In the second step, for each cross-sectional imaging on CBCT, the hemimandibles were evaluated regarding the presence of the AL, which was classified as rectilinear or curvilinear, and the measurement of its length was obtained (de Oliveira-Santos et al., 2011). The length was obtained by the linear distance between the most anterior border of the mental foramen to the most anterior margin of the anterior loop (ALL, anterior loop length). Slice thickness of panoramic reconstructions were 25 $\mathrm{mm}$, so that the entire course of the canal could be visualized, including the mental foramen, without impairing image superimposition. For the cross-sections, the anterior loop was determined by counting the number of sequential $1 \mathrm{~mm}$ slices displaying two round hypodense images (corresponding to the upper and lower segments of the mandibular canal, typically ending in an "8-like" shape anteriorly), from the anterior-most image of the mental foramen and start point of the incisive canal. The number of parasagittal cuts containing the ALL was counted and multiplied by 0.25 , thus achieving the ALL measurement.

The occlusal plane served as the reference for the cross-sections since the slices were reconstructed following the occlusal plane. Before starting the evaluation of parasagittal cuts, the occlusal plane was aligned, avoiding inclination and rotation of the image due the inclinations of the head during image acquisition. Thus centralized parabolic curve (axial), leading the points up dental crowns (Fig. 1).

One oral and maxillofacial radiologist with experience in manipulation and interpretation of CBCT images performed the measurements. Reliability was assessed using replicate measurements and intraobserver reliability was estimated based on 2 measurements performed at the right and left sides of the mandible with a 20-day interval to avoid dilution of error. The final mean values of each measurement resulted from the average of the 2 measurements.

\section{RESULTS}

This research was realized without complications. No differences in image quality or variations in the analyses were observed; other situation involved in this study as economical cost of the exam, quantity and quality of radiation to the patient, time to take the exam or another situation are evaluated in other research in progress, so this report shows only the anatomical situation of the mental nerve anterior loop.

The frequencies of the AL identified through PR and CBCT were different. In PR the loop was identified in $42.6 \%$ of cases, and only $12.8 \%$ were bilateral. In contrast, the loop was detected in $29.8 \%$ of the samples using CBCT, with $6.4 \%$ being bilateral (Table I). Out of the 47 patients studied, $14(29.8 \%)$ presented the AL: three were bilateral, seven unilateral right and four unilateral left. Making calculations based hemimandibles study, 94, out of which 17 (18.1\%) out of the loop anterior mental nerve was bilateral and $35.3 \%$, $41.2 \%$ and $23.5 \%$ unilateral right-sided left.

Statistical comparison between PR and CBCT showed that the PR led to false-positive diagnostics of the loop in the samples (Table II). On the other hand, the length of the AL showed variations between the right and left side showing distances from $3.0 \mathrm{~mm}$ to $11.2 \mathrm{~mm}$ in the evaluations.

Table I. Distribution of the conditions of AL in 47 patients using panoramic radiography (PR) and cone beam computed tomography images (CBCT), bilaterally.

\begin{tabular}{lcc}
\hline \multirow{2}{*}{ Side } & \multicolumn{2}{c}{ n (\%) } \\
\cline { 2 - 3 } & PR & TCCB \\
\hline Absent & $27(57.4 \%)$ & $33(70.2 \%)$ \\
Right & $9(19.2 \%)$ & $7(14.9 \%)$ \\
Left & $5(10.6 \%)$ & $4(8.5 \%)$ \\
Both & $6(12.8 \%)$ & $3(6.4 \%)$ \\
Total & \multicolumn{2}{c}{$47(100.0 \%)$} \\
\hline
\end{tabular}

Table II. Correlation between panoramic radiography (PR) and cone beam computed tomography $(\mathrm{CBCT})$ evaluation for the detection of the anterior loop of the mental nerve in the 47 subjects.

\begin{tabular}{llllll}
\hline \multirow{2}{*}{ Side } & \multirow{2}{*}{ PR } & \multicolumn{2}{c}{ CBCT } & \multirow{2}{*}{ Kappa } & \multirow{2}{*}{ IC95\% } \\
\cline { 3 - 4 } & & Presence & Absence & & \\
\hline Rigth & Presence & $3(6.4 \%)$ & $12(25.5 \%)$ & -0.02 & $-0.29 ; 0.25$ \\
& Absence & $7(14.9 \%)$ & $25(53.2 \%)$ & & \\
Left & Presence & $2(4.3 \%)$ & $9(19.2 \%)$ & 0.05 & $-0.24 ; 0.34$ \\
& Absence & $5(10.6 \%)$ & $31(66.0 \%)$ & & \\
\hline
\end{tabular}


COUTO-FILHO, C. E. G.; DE MORAES, P. H.; ALONSO, M. B. C.; HAITER-NETO, F.; OLATE, S. \& ALBERGARIA-BARBOSA, J. R. Accuracy in the diagnosis of the position of the mental nerve loop. A comparative study between panoramic radiography and cone beam computed tomography. Int. J. Morphol., 33(1):327-332, 2015.

\section{DISCUSSION}

Methodology of Measurement. Radiographs have been the dominant source for diagnostic information on the maxillofacial complex (Jacobs et al.). However, other study has shown that the reliability of the panoramic radiographs, when planning for implant placement in the interforaminal region of the mandible, may be limited (Kuzmanovic et al., 2003). One of the disadvantages of panoramic images is the geometric distortion of the anatomical structures (Garay \& Olate; Garay et al.; Garay \& Cantín, 2013). Distortions of the panoramic images in the horizontal and vertical planes, especially in the anterior region, depend on the anatomical variations between arch curvatures - focal plane shape - and operator error in patient positioning affects the utility of panoramic images to provide accurate measurements (Laster et al., 2005; Stramotas et al., 2002).

Our results are in agreement with Kuzmanovic et al., regarding the limitation of using panoramic radiographs, when planning for implant placement in the interforaminal region of the mandible. The interpretation of the panoramic radiograph did not show accuracy in diagnosis of the presence of $\mathrm{AL}$, as well as inferred the underestimation or overestimation of the size of the AL when compared with the CBCT. Thus, panoramic radiography is unreliable in identifying the AL (Table I), which is in agreement with other studies that use exclusively in implant planning in the region is questionable interforaminal (Mardinger et al.; Kaya et al., 2008).

The picture quality and contrast between adjacent structures are important factors in the task of identifying various anatomical structures and possible injuries. CBCT has been proven as reliable imaging technique for the maxillofacial region (Kobayashi et al., 2004; Lou et al., 2007; Uchida et al., 2007, 2009), extremely useful in evaluating bone, once it provides images with high contrast without overlapping images and displays real action.

The use of CBCT for oral and maxillofacial imaging holds the promise of overcoming these obstacles while providing more accurate craniometrical and diagnostic information than conventional radiographic techniques (Ludlow et al., 2007; Martínez et al., 2013). Furthermore, computed tomography is the best method to obtain minimally invasive and correct preoperative measurement of the $\mathrm{AL}$ in living patients (Mischkowski et al., 2006; Chiu et al., 2006).

Despite of the prevalence of AL varies considerably in the literature, our results are in agreement with others modalities of studies such as: anatomic cadavers studies; use of panoramic radiographs as well as in CBCT (Kuzmanovic et al.; Uchida et al., 2007, 2009; Ngeow et al., 2009). Using panoramic radiographs, AL was detected in $42.6 \%$ of the cases, while using CBCT it was found in only $29.8 \%$ of them (Table III).

The method used to measure the extent of previous $\mathrm{AL}$ is relevant. Conventional radiography does not seem to show the true anatomical shape and extent of the AL. Confirming the reliability of $\mathrm{CBCT}$ as a tool to determine the extent of previous AL, differences of less than $0.1 \mathrm{~mm}$ between anatomical measurements performed on cadavers and CBCT images were found (Kuzmanovic et al.; Uchida et al., 2007, 2009). Our results ranged from $2.5 \mathrm{~mm}$ to 3.25 $\mathrm{mm}$ length, which is consistent with other studies (Table III).

Anatomical Considerations. The length of AL ranging from $0 \mathrm{~mm}$ to $9 \mathrm{~mm}$ has been reported (Table III) and the longest loop reported in the literature was $11 \mathrm{~mm}$ (Neiva et al., 2004).

Although some potential influence of ethnicgeographic variability (Liang et al., 2009), methodological differences and lack of clear definitions for AL are recurrent in the literature and may yield differences in prevalence findings and measures. The term AL refers to the curvature of the nerve chin in a "loop", which surpass the earlier level of mental foramen returns toward the right in the upper, lateral and distal.

A measure of the extent of previous AL is a feature that should be viewed cautiously. Extensions of AL greater than $2 \mathrm{~mm}$ are clinically relevant, especially for installation of dental implants (de Oliveira-Santos et al.) or for application of mental osteotomy (Fuentes et al., 2014). Where such values corroborate our results, when the $\mathrm{AL}$ present, the minimum length of $2.5 \mathrm{~mm}$ found, should to be considered when planning surgery.

Clinical Considerations. Clinically, if an implant was placed in contact with the anterior loop of the mental nerve, the implant would likely fail because of increased edema and a lack of supportive hard tissue together with increasing soft tissue in the area. Injury to the mental nerve or inferior alveolar nerve should be carefully considered when placing an implant in this area.

Fixed distances above the mental foramen, supposedly safe, were recommended in the past (Kuzmanovic et al.). However, the results of this study in accordance with the results of other studies (Uchida et al., $2007,2009)$ show that beyond the limitation of radiographic conventional anatomic variability cannot be neglected. 
COUTO-FILHO, C. E. G.; DE MORAES, P. H.; ALONSO, M. B. C.; HAITER-NETO, F.; OLATE, S. \& ALBERGARIA-BARBOSA, J. R. Accuracy in the diagnosis of the position of the mental nerve loop. A comparative study between panoramic radiography and cone beam computed tomography. Int. J. Morphol., 33(I):327-332, 2015.

Table III. Comparison for directed measurement of the anterior loop length in some studies from 1994 to 2009.

\begin{tabular}{|c|c|c|c|c|}
\hline Authors & Sample & $\mathbf{n}$ & Incidence AL & Mean \pm SD (Range) \\
\hline \multirow[t]{3}{*}{ Bavitz et al. (1993) } & Cadavers & 24 & 11 & --- \\
\hline & & Dentate group $(n=24)$ & --- & $0.2 \pm 0.3(0.0-1.0)$ \\
\hline & & Edentulous group $(n=23)$ & --- & $0.0 \pm 0.0(0.0-0.0)$ \\
\hline Solar et al. (1994) & Cadavers & 37 & 60 & $1.0 \pm 1.2(0.0-5.0)$ \\
\hline Rosenquist (1996) & Patients & 58 & 26 & $0.15(0.0-1.0)$ \\
\hline Mardinger et al. (2000) & Cadavers & 46 hemimandibles & 28 & $1.05 \pm 0.47(0.4-2.19)$ \\
\hline \multirow{2}{*}{$\begin{array}{l}\text { Kuzmmanovic et al. } \\
\text { (2003) }\end{array}$} & Cadavers & 22 (44 hemimandibles) & --- & $1.2 \pm 0.9(0.11-3.31)$ \\
\hline & Caucasian descent & --- & --- & --- \\
\hline Neiva et al. (2004) & Caucasian skulls & 22 & 88 & $4.13 \pm 2.04(1.0-11.0)$ \\
\hline \multirow[t]{2}{*}{ Hwang et al. (2005) } & Cadavers & 30 fresh hemimandibles & --- & $5.0(1.9)$ \\
\hline & Korean & 50 dry hemimandibles & --- & --- \\
\hline \multirow[t]{2}{*}{ Uchida et al. (2007) } & Cadavers & --- & --- & --- \\
\hline & Japanese & 38 (75 hemimandibles) & 62.7 & $1.5 \pm 1.4(0.0-6.0)$ \\
\hline \multirow[t]{2}{*}{ Uchida et al. (2009) } & Cadavers & 71(140 hemimandibles) & 71 & $2.2(0.8)$ \\
\hline & Japanese & --- & --- & --- \\
\hline
\end{tabular}

Therefore, sectional tests, such as CBCT should be used for evaluation of AL. Thus, the surgeons must familiarize themselves with anatomic information obtained, by measuring the length of the previous loop on a case-by-case basis once the recommendations of fixed distances to the anatomical landmarks of the AL are unreliable. Implant and Osteotomy (Hwang et al., 2005) could be modified in according with AL of the IAN.

Although it is known that the linear measurements obtained in CBCT images represent real values, an important aspect to be considered is the transfer of these measures for clinical practice. Ideally, measurements should be easily reproduced during surgery. However, the plan used as a reference for the implementation of measures is often overlooked.

According to the results of this study, the frequency of AL is low. Thus, it can be assumed that it is a not common condition in the population studied; considering that LA has a range of $0 \mathrm{~mm}$ to $11 \mathrm{~mm}$, it becomes extremely relevant when present.

COUTO-FILHO, C. E. G.; DE MORAES, P. H.; ALONSO, M. B. C.; HAITER-NETO, F.; OLATE, S. \& ALBERGARIA-BARBOSA, J. R. Precisión en el diagnóstico del bucle del nervio mental. Estudio comparativo entre radiografía panorámica y tomografía computadorizada de haz cónico. Int. J. Morphol., 33(1):327-332, 2015.

RESUMEN: Implantes dentales y la osteotomía de mentón son realizadas en el cuerpo mandibular y el nervio mental es un importante limite anatómico. El objetivo de esta investigación es conocer la posición del bucle del nervio mental comparando resultados entre radiografia panorámica y tomografía computadorizada de haz cónico (TCHC). Fueron analizadas 94 hemimandíbulas; la muestra de pacientes de sexo feminino y masculino con edades fluctuando entre 18 y 52 años (edad media, 35 años) seleccionados de la base de datos de pacientes de la División de Radiología de la Facultad de Odontología de Piracicaba, Universidad Estadual de Campinas; el bucle anterior (BA) del nervio mental fue evaluado según su presencia o ausencia, el cual fue clasificado como rectilíneo o curvilíneo obteniéndose el largo total del bucle; las observaciones fueron realizadas en radiografías panorámicas digitales (RP) y en TCHC de acuerdo a técnicas de rutina. La frecuencia de identificación del BA en RP y TCHC fue diferente: en la PR, el BA se identificó en un 42,6\% de los casos y solo el 12,8\% fue bilateral. En contraste, el BA fue detectado en el $29,8 \%$ de la muestra utilizando TCHC, con un 6,4\% bilateral; la comparación estadística entre RP y TCHC muestra que la RP lleva a diagnósticos falsos positivos de la muestra de BA. De acuerdo con los resultados de este estudio, la frecuencia de BA es baja. Por este motivo se puede asumir que esta es una condición anatómica poco frecuente en la población estudiada.

PALABRAS CLAVE: Radiografía panorámica; Tomografía computadorizada de haz cónico; Bucle del nervio mental.

\section{REFERENCES}

Bavitz, J. B.; Harn, S. D.; Hansen, C. A. \& Lang, M. An anatomical study of mental neurovascular bundle-implant relationships. Int. J. Oral Maxillofac. Implants, 8(5):563-7, 1993.

Beltrán, V.; Cantín, M.; Fuentes Fernández, R. \& Engelke, W. Bilateral Presence of mandibular incisive canal. An anatomical structure with clinical relevance. Int. J. Morphol., 29(2):543-9, 2011.
Benninger, B.; Miller, D.; Maharathi, A. \& Carter, W. Dental implant placement investigation: is the anterior loop of the mental nerve clinically relevant? J. Oral Maxillofac. Surg., 69(1):182-5, 2011.

Chiu, W. K.; Luk, W. K. \& Cheung, L. K. Three-dimensional accuracy of implant placement in a computer-assisted navigation system. Int. J. Oral Maxillofac. Implants, 21(3):465-470, 2006. 
COUTO-FILHO, C. E. G.; DE MORAES, P. H.; ALONSO, M. B. C.; HAITER-NETO, F.; OLATE, S. \& ALBERGARIA-BARBOSA, J. R. Accuracy in the diagnosis of the position of the mental nerve loop. A comparative study between panoramic radiography and cone beam computed tomography. Int. J. Morphol., 33(I):327-332, 2015.

Deeb, G. R.; Dierks, E. \& So, Y. T. Sensory nerve conduction study of the mental nerve. Muscle Nerve, 23(7):1121-4, 2000.

de Oliveira-Santos, C.; Souza, P. H.; de Azambuja Berti-Couto, S.; Stinkens, L.; Moyaert, K.; Rubira-Bullen, I. R. \& Jacobs, R. Assessment of variations of the mandibular canal through cone beam computed tomography. Clin. Oral Invest., 16(2):387-93, 2012.

Fuentes, R.; Cantin, M.; Navarro, P.; Borie, E.; Beltran, V. \& Bucchi, C. Characterization of anatomical structures using panoramic radiographs: the mental foramen. Int. J. Morphol., 32(4):1423-9, 2014.

Garay, I. \& Cantin, M. Accessory Mental Foramina Assessed by ConeBeam Computed Tomography: Report of Unilateral and Bilateral Detection. Int. J. Morphol., 31(3):1104-8, 2013.

Garay, I. \& Olate, S. Currrent considerations in the study of image of soft tissue calcification in mandibular angle area. Int. J. Odontostomat., 7(3):455-64, 2013

Garay, I.; Netto, H. D. \& Olate, S. Soft tissue calcified in mandibular angle area observed by means of panoramic radiography. Int. J. Clin. Exp. Med., 7(1):51-6, 2014.

Hwang, K.; Lee, W. J.; Song, Y. B. \& Chung, I. H. Vulnerability of the inferior alveolar nerve and mental nerve during genioplasty: an anatomic study. J. Craniofac. Surg., 16(1):10-4, 2005.

Jacobs, R.; Mraiwa, N.; vanSteenberghe, D.; Gijbels, F. \& Quirynen, M. Appearance, location, course, and morphology of the mandibular incisive canal: an assessment on spiral CT scan. Dentomaxillofac. Radiol., 31(5):322-7, 2002.

Kaya, Y.; Sencimen, M.; Sahin, S.; Okcu, K. M.; Dogan, N. \& Bahcecitapar,

M. Retrospective radiographic evaluation of the anterior loop of the mental nerve: comparison between panoramic radiography and spiral computerized tomography. Int. J. Oral Maxillofac. Implants, 23(5):919-25, 2008

Kobayashi, K.; Shimoda, S.; Nakagawa, Y. \& Yamamoto, A. Accuracy in measurement of distance using limited cone-beam computerized tomography. Int. J. Oral Maxillofac. Implants, 19(2):228-31, 2004.

Kuzmanovic, D. V.; Payne, A. G.; Kieser, J. A. \& Dias, G. J. Anterior loop of the mental nerve: a morphological and radiographic study. Clin. Oral Implants Res., 14(4):464-71, 2003.

Laster, W. S.; Ludlow, J. B.; Bailey, L. J.; \& Hershey, H. G. Accuracy of measurements of mandibular anatomy and prediction of asymmetry in panoramic radiographic images. Dentomaxillofac. Radiol., 34(6):343-9, 2005.

Liang, X.; Jacobs, R.; Corpas, L. S.; Semal, P. \& Lambrichts, I. Chronologic and geographic variability of neurovascular structures in the human mandible. Forensic. Sci. Int., 190(1-3):24-32, 2009.

Lou, L.; Lagravere, M. O.; Compton, S.; Major, P. W. \& Flores-Mir, C. Accuracy of measurements and reliability of landmark identification with computed tomography (CT) techniques in the maxillofacial area: a systematic review. Oral Surg. Oral Med. Oral Pathol. Oral Radiol. Endod., 104(3):402-11, 2007.

Ludlow, J. B.; Laster, W. S.; See, M.; Bailey, L. J. \& Hershey, H. G. Accuracy of measurements of mandibular anatomy in cone beam computed tomography images. Oral Surg. Oral Med. Oral Pathol. Oral Radiol. Endod., 103(4):534-42, 2007.
Mardinger, O.; Chaushu, G.; Arensburg, B.; Taicher, S. \& Kaffe, I. Anterior loop of the mental canal: an anatomical-radiologic study. Implant. Dent., 9(2):120-5, 2000.

Martínez, F.; Olate, S.; Almeida, A. \& Vásquez, B. Unilateral double accessory mental foramen. Case report. Int. J. Morphol., 31(4):1470$2,2013$.

Mischkowski, R. A.; Zinser, M. J.; Neugebauer, J.; Kübler, A. C. \& Zöller, J. E. Comparison of static and dynamic computer-assisted guidance methods in implantology. Int. J. Comput. Dent., 9(1):23-35, 2006.

Mucci, S. J. \& Dellon, A. L. Restoration of lower-lip sensation: neurotization of the mental nerve with the supraclavicular nerve. J. Reconstr. Microsurg., 13(3):151-5, 1997.

Neiva, R. F.; Gapski, R. \& Wang, H. L. Morphometric analysis of implantrelated anatomy in Caucasian skulls. J. Periodontol., 75(8):1061-7, 2004.

Ngeow, W. C.; Dionysius, D. D.; Ishak, H. \& Nambiar, P. A radiographic study on the visualization of the anterior loop in dentate subjects of different age groups. J. Oral Sci., 51(2):231-7, 2009.

Rosenquist, B. Is there an anterior loop of the inferior alveolar nerve? Int. J. Periodontics Restorative Dent., 16(1):40-5, 1996.

Solar, P.; Ulm, C.; Frey, G. \& Matejka, M. A classification of the intraosseous paths of the mental nerve. Int. J. Oral Maxillofac. Implants, 9(3):33944, 1994.

Stramotas, S.; Geenty, J. P.; Petocz, P. \& Darendeliler, M. A. Accuracy of linear and angular measurements on panoramic radiographs taken at various positions in vitro. Eur. J. Orthod., 24(1):43-52, 2002.

Uchida, Y.; Yamashita, Y.; Goto, M. \& Hanihara, T. Measurement of anterior loop length for the mandibular canal and diameter of the mandibular incisive canal to avoid nerve damage when installing endosseous implants in the interforaminal region. J. Oral Maxillofac. Surg., 65(9):1772-9, 2007.

Uchida, Y.; Noguchi, N.; Goto, M.; Yamashita, Y.; Hanihara, T.; Takamori, H.; Sato, I.; Kawai, T. \& Yosue, T. Measurement of anterior loop length for the mandibular canal and diameter of the mandibular incisive canal to avoid nerve damage when installing endosseous implants in the interforaminal region: a second attempt introducing cone beam computed tomography. J. Oral Maxillofac. Surg., 67(4):744-50, 2009.

Wismeijer, D.; van Waas, M. A.; Vermeeren, J. I. \& Kalk, W. Patients' perception of sensory disturbances of the mental nerve before and after implant surgery: a prospective study of 110 patients. Br. J. Oral Maxillofac. Surg., 35(4):254-9, 1997.

\section{Correspondence to: \\ Prof. Sergio Olate, $\mathrm{PhD}$ \\ CIMA \& CEMyQ Research Group \\ Division of Oral and Maxillofacial Surgery \\ Universidad de La Frontera \\ Claro Solar 115, Of. 414-A \\ Temuco - CHILE}

Recibido : 11-11-2014

Aceptado: 12-01-2015

Email: sergio.olate@ufrontera.cl 